\author{
İsmet Toksöz \\ Ferit Kılıçkaya \\ Mehmet Akif Ersoy University, \\ 15030, Burdur, Turkey
}

\title{
Review of Journal Articles on Washback in Language Testing in Turkey (2010-2017)
}

\begin{abstract}
The aim of the current paper is to review the national and international journal articles on washback in language testing in Turkey between 2010 and 2017. The studies have been obtained from several databases such as ERIC and ScienceDirect, and the journal websites. The studies conducted on washback in Turkish contexts are divided into two main groups: the studies conducted on washback effects of high-stakes exams in Turkey, and the studies conducted in state and private schools in Turkey. The studies are discussed with respect to their main findings, strengths, and weaknesses and most of these studies are based on the national examinations such as YDS (Foreign Language Exam) and their washback effects on examinees.

Keywords: washback; high-stakes exams; language testing; foreign language exams
\end{abstract}

1. Introduction

This paper reviews the studies conducted on washback effects in language teaching in Turkey between 2010 and 2017. Since washback in language teaching is a growing area of research in Turkey, the current paper aims to review the studies to indicate the current 
findings regarding the washback effects of exams in Turkey. The studies have been obtained from several databases such as ERIC and ScienceDirect. Majority of these studies reviewed are practiceoriented and address issues about teaching practices at schools and universities. The articles are grouped into these two headings: the studies conducted on washback effects of high-stakes exams in Turkey, and the studies conducted on washback effects of exams in state and private schools in Turkey.

Washback or Backwash refers to the effects of assessment practices on students, teachers, and administrators, and indirectly on schools and communities as Kılıçkaya (2016) states as well: "any assessment made, be it formative or summative, or teacher made and nation-wide, has an effect on both learners and teachers" (p. 117). Hughes (2003) describes washback as "the effect of testing on teaching and learning" (p. 1). In this context, Karabulut (2007) states that if a test is significant for the test taker, it displays strong washback; yet, if it is not fundamental at all, it presents weak washback. In this regard, it could be stated that high-stakes exams administered by ÖSYM (Measurement, Selection and Placement Center) such as YDS (Foreign Language Exam), E-YDS (Electronic Foreign Language Exam), LYS (Bachelor Placement Exam), YGS (Higher Education Entrance Exam), KPSS (State Employees Selection Exam) and the like would probably have strong washback effects on test takers. There are two kinds of washback: beneficial and harmful washback. It could be asserted that "a test providing beneficial washback positively influences what and how teachers teach, what and how learners learn, and offers learners a chance to prepare for the test" (Brown \& Abeywickrama, 2010: 38). Moreover, Brown and Abeywickrama (2010) argue that a test that provides beneficial washback is more formative rather than summative, and gives learners necessary feedback for their language development. On the other hand, if a test leads to an undesirable effect on teaching and learning; for instance, both learners and teachers do not want to learn and teach due to pressure of this test, it could be stated that the test leads to harmful washback effect on students and teachers (Alderson \& Wall, 1993). 
Washback could be seen as a leading issue in language testing, and it is a key subject. The studies conducted on washback in Turkey appear to have focused instructional methodologies and teaching stages, and students' attitudes and perceptions about the exams (Yıldırım, 2010; Özmen, 2011a, 2011b; Akpınar \& Çakıldere, 2013; Hatipoğlu, 2016; Kılıçkaya, 2016; Külekçi, 2016; Sayın \& Aslan, 2016). With this regard, this paper tries not only to present information about experimental parts of the studies on washback in Turkey and but also to propose some criticisms about the studies. The journal articles conducted on washback in language testing have been summarized in Table 1.

Table 1. The journal articles on washback in language testing in Turkey

\begin{tabular}{|c|c|c|c|}
\hline Author(s) & Year & Methodology & Main Findings \\
\hline Akın & 2016 & $\begin{array}{l}\text { Qualitative research } \\
\text { design, document } \\
\text { analysis, } 2013 \text { spring } \\
\text { and } 2015 \text { fall YDS } \\
\text { questions. }\end{array}$ & $\begin{array}{l}\text { The test assessed only test takers' } \\
\text { reading, vocabulary and grammar skills. } \\
\text { Listening, speaking, and writing skills } \\
\text { were not assessed. }\end{array}$ \\
\hline $\begin{array}{l}\text { Akpınar \& } \\
\text { Çakıldere }\end{array}$ & 2013 & $\begin{array}{l}\text { Survey questionnaire, } \\
\text { descriptive statistical } \\
\text { analysis, } 103 \text { academics } \\
\text { at Nevşehir University, } \\
\text { Turkey. }\end{array}$ & $\begin{array}{l}K P D S \text { and } \ddot{U} D S \text { had positive washback } \\
\text { effects on reading skill. The participants } \\
\text { studied to the test, ignoring productive } \\
\text { skills and listening. }\end{array}$ \\
\hline $\begin{array}{l}\text { Cinkara \& } \\
\text { Tosun }\end{array}$ & 2017 & $\begin{array}{l}\text { Mixed-method research } \\
\text { design, response sheets } \\
\text { and interviews, } 49 \\
\text { participants from } \\
\text { Gaziantep University, } \\
\text { Turkey. }\end{array}$ & $\begin{array}{l}\text { The test did not meet students' } \\
\text { expectations of a test. The test was not } \\
\text { strong enough in terms of assessing the } \\
\text { necessary skills in language learning, } \\
\text { which indicated the negative washback } \\
\text { effect of this test on test takers. }\end{array}$ \\
\hline Hatipoğlu & 2016 & $\begin{array}{l}\text { Mixed-method research } \\
\text { design, survey } \\
\text { questionnaire and } \\
\text { interview, } 50 \text { pre- } \\
\text { service English } \\
\text { language teachers at }\end{array}$ & $\begin{array}{l}\text { The exam affected and even directed } \\
\text { how English was learned and taught in } \\
\text { Turkey. EUEE had negative washback } \\
\text { effect on English language teaching and } \\
\text { learning curriculum in Turkey. Most } \\
\text { high school teachers did not teach }\end{array}$ \\
\hline
\end{tabular}




\begin{tabular}{|c|c|c|c|}
\hline Author(s) & Year & Methodology & Main Findings \\
\hline & & $\begin{array}{l}\text { Middle East Technical } \\
\text { University, Turkey. }\end{array}$ & $\begin{array}{l}\text { English but helped the students master } \\
\text { the format of ESUEE. }\end{array}$ \\
\hline Kılıçkaya & 2016 & $\begin{array}{l}\text { Qualitative research } \\
\text { design, content analysis, } \\
30 \text { teachers at secondary } \\
\text { schools, Burdur, } \\
\text { Turkey. }\end{array}$ & $\begin{array}{l}\text { TEOG had a negative washback effect } \\
\text { on language-teaching practices. } T E O G \\
\text { was a barrier to cover the essential skills } \\
\text { such as listening, speaking, and writing. } \\
\text { TEOG had a large influence on course } \\
\text { book selection, the medium of } \\
\text { instruction, classroom assessment, and } \\
\text { learners' anxiety. TEOG had a negative } \\
\text { washback effect on students, teachers, } \\
\text { parents, and administrators. }\end{array}$ \\
\hline Külekçi & 2016 & $\begin{array}{l}\text { Qualitative research } \\
\text { design, descriptive } \\
\text { analysis, YDS. }\end{array}$ & $\begin{array}{l}Y D S \text { had a positive washback effect } \\
\text { since } Y D S \text { stimulated test takers to study } \\
\text { English more. } Y D S \text { had a negative } \\
\text { washback effect on test takers as test } \\
\text { takers spent their time studying for the } \\
\text { multiple-choice technique. } Y D S \text { focused } \\
\text { on grammatical and textual English and } \\
\text { disregarded practical usage of the } \\
\text { language. }\end{array}$ \\
\hline
\end{tabular}

Özmen 2011a Mixed-method research Due to KPSS, students appeared to have design, comparative ignored their faculty program and spent analysis, 164 pre-service their limited income for KPSS course. teachers at 9 universities KPSS affected students' motivation in Ankara, Turkey. negatively. KPSS had negative washback effects on test takers, and college students were kept away from their academic life directly or indirectly due to KPSS.

Özmen 2011b Qualitative research $\ddot{U} D S$ had a negative washback effect on design, comparative analysis, 8 candidate academics, and 4 test takers in terms of learning a foreign language. For some participants, $\ddot{U} D S$ graduate students in appeared to be a memory game as it Ankara, Turkey. mostly assessed recognition and focused on only vocabulary and grammar. 


\begin{tabular}{|c|c|c|c|}
\hline Author(s) & Year & Methodology & Main Findings \\
\hline Paker & 2012 & $\begin{array}{l}\text { Qualitative research } \\
\text { design, document } \\
\text { analysis, achievement } \\
\text { tests given at } 13 \\
\text { universities in Turkey. }\end{array}$ & $\begin{array}{l}\text { All the skills and the subskills were } \\
\text { tested in almost all the schools. All } \\
\text { these language exams had positive } \\
\text { washback effects on students. }\end{array}$ \\
\hline Sarıçoban & 2011 & $\begin{array}{l}\text { Qualitative research } \\
\text { design, document } \\
\text { analysis, two exams } \\
\text { conducted at a high } \\
\text { school, Ankara, Turkey. }\end{array}$ & $\begin{array}{l}\text { Teaching and testing did not correspond } \\
\text { with each other, and teachers did not } \\
\text { include the topics that were covered in } \\
\text { class in the exams they prepared. The } \\
\text { teachers asked about the topics that } \\
\text { were not covered in the class. The } \\
\text { exams had negative washback effects } \\
\text { on students. }\end{array}$ \\
\hline
\end{tabular}

Sayın \& 2016 Quantitative research Listening and speaking skills were Aslan design, survey questionnaire, 74 ignored in students' preparation process and in the application of the written Turkish freshman ELT exam. LYS had a negative washback students studying at two effect on test takers. Students did not universities in Samsun, feel confident enough in speaking and Turkey. listening although they passed the language exam and were admitted to the department.

Şenel \& 2011 Mixed-method, Tütüniş experimental research
design, 42 students at Aydın University, İstanbul, Turkey.

Yavuzer \& 2012 Mixed-method research Göver design, survey questionnaire, 121 academics at Nevşehir University, Turkey.

Yeşilyurt 2016 Qualitative research design, metaphor
Language anxiety resulted from fear of making mistakes and using wrong expressions. Writing exams applied in Turkish universities had negative washback effects on university students.

$K P D S$ and $\ddot{U} D S$ prevented academics from doing academic/scientific studies. $K P D S$ and $\ddot{U} D S$ assessed only grammar and reading skills while ignoring listening and productive skills. KPDS and $\ddot{U} D S$ had negative washback effects on academics in Turkey.

FLTs were seen as an obstacle to academics' future scientific studies. 


\begin{tabular}{llll}
\hline Author(s) & Year & \multicolumn{1}{c}{ Methodology } & \multicolumn{1}{c}{ Main Findings } \\
\hline Ylicitation, 110 & $\begin{array}{l}\text { FLTs had negative washback effects on } \\
\text { academics at Atatürk } \\
\text { University, Turkey. }\end{array}$ & $\begin{array}{l}\text { test takers influencing their both } \\
\text { personal and professional life. }\end{array}$ \\
& 2010 & $\begin{array}{l}\text { Mixed-method research } \\
\text { design, descriptive } \\
\text { statistics, 6 EFL } \\
\text { instructors at a state } \\
\text { university and 70 EFL } \\
\text { students. }\end{array}$ & $\begin{array}{l}\text { ECFLEE had negative washback on } \\
\text { both teachers and students. } \text { ECFLUEE } \\
\text { assessed only reading skill, grammar, } \\
\text { and vocabulary. } \text { ECFLUEE did not } \\
\text { assess writing and speaking skills. }\end{array}$ \\
\hline
\end{tabular}

2. The studies conducted on washback effects of high-stakes exams in Turkey

When literature is reviewed, as stated above, most studies conducted on washback in language testing in Turkey appear to be on highstakes exams in Turkey. As Hatipoğlu (2016) states, "In Turkey, the education system is very exam oriented" (p. 137) and "due to the pressure and consequences attached to the high-stakes tests, several effects can be observed" (Kılıçkaya, 2016: 117). The national exams applied in Turkish contexts include YDS, E-YDS, LYS, YGS, and $K P S S$, and these exams have been subject to research in terms of their washback effects on students and teachers.

In his study, Yildırım (2010) investigated students' and teachers' teaching and learning practices in the preparation process for ECFLUEE (English Component of the Foreign Language University Entrance Exam). The aim of the study was to find out how EFL (English as a foreign language) students and instructors viewed ECFLUEE with regard to learning a foreign language. A structured questionnaire and semi-structured interviews were utilized in this mixed-method study. While the questionnaire was analyzed via descriptive statistics, the interviews were audio-recorded and transcribed in data analysis process. The participants of the study were 6 EFL instructors at a state university and 70 EFL students who had studied the prep class. The results of the study indicated that ECFLUEE had negative washback on both teachers and students. The 
exam appeared to assess only reading skill, grammar and vocabulary knowledge of the students; however, in foreign language learning process, all four skills and their subskills had to be studied and assessed. In this context, high school students preparing for ECFLUEE seemed to be studying only reading, grammar, and vocabulary. Thus, they learned to the test since their listening, speaking and writing skills were not assessed in the exam. Therefore, these students had much difficulty in speaking and writing in English in their courses during their first year at the university, which indicated negative washback effect of ECFUEE. However, the study was conducted with the participants from the same university. Further research with different participants in several universities might give more enlightening and generalizable results for the similar contexts in Turkey.

Özmen (2011a), on the other hand, studied the washback effects of KPSS on pre-service teachers studying in ELT, linguistics, and English/American literature programs. The researcher investigated whether KPSS could have positive or negative washback on test takers and its implications on students' professional development. In this mixed-method study, a questionnaire and semi-structured interviews were applied to 164 pre-service teachers who were studying in 9 universities in Ankara, Turkey and attending a private KPSS course. The questionnaire items were analyzed via descriptive statistics, and coding was done using Glaser and Strauss' (1967) constant comparative analysis in the data analysis of the interviews. This informative study that had an adequate number of participants revealed enchanting findings. Due to KPSS, students appeared to have ignored their faculty program and spent their limited income for KPSS course. The results of the study also revealed that KPSS also affected their motivation negatively in their studies to become a teacher in the future. Furthermore, the participants reported that KPSS was not a reliable test that could determine good and bad teachers. Another harmful impact of KPSS on undergraduate students was that those who wanted to have a Master's Degree did not have any time to study for the academic exams to be accepted to such a program. Considering 
all these, it could be asserted that KPSS created negative washback effects on test takers, and college students were kept away from their academic life directly or indirectly because of KPSS. However, the study could be conducted also with the students who were not following a private KPSS course since they would also take KPSS to become a teacher. It could be found out whether there was a significant difference between the students enrolled in a KPSS course and the others who were not in terms of attitudes towards KPSS. In addition, the reasons behind not following a specific course for KPSS could also be identified.

In another study, Özmen (2011b) investigated the possible washback effect of $\ddot{U} D S$ (Inter-University Foreign Language Examination) in Turkey. He tried to define how $\ddot{U} D S$ affected language learning practices of candidate academics and graduate students. The data collection instruments of the study included semistructured interviews and these interviews were coded via Glaser and Strauss' (1967) constant comparative analysis in the data analysis process. The participants of the study were 8 candidate academics and 4 graduate students from Ankara, Turkey, and they all attended a private $\ddot{U} D S$ course. The results indicated that $\ddot{U} D S$ led to the negative washback effect on test takers in terms of learning a foreign language. The results also revealed that the exam appeared to be a procedure for examinees since they had to pass it in order to be accepted to a graduate program or to be promoted at the university. It was also determined that for some participants $\ddot{U} D S$ appeared to be a memory game as it mostly assessed recognition and focused on only vocabulary and grammar. Although Özmen (2011b) reported that $\ddot{U} D S$ did not only have a micro impact on a small group of test takers but also had a macro impact on a large group studying and working at universities, the findings of the study might not be generalizable to other contexts since the number of the participants was limited. More academics from different districts of Turkey could have been interviewed about $\ddot{U} D S$. In addition, the students enrolled at different universities who had taken $\ddot{U} D S$ exam might have also participated in the study. Moreover, the study used only interviews to gather data; 
quantitative data could have also been collected to yield more supportive results.

Yavuzer and Göver (2012) investigated the foreign language proficiency of academics in Nevşehir University, Turkey and academics' attitudes towards high-stakes language proficiency tests namely KPDS (State Employees Language Exam) and $\ddot{U} D S$ applied in Turkish contexts. The purpose of the study was to evaluate the content of $K P D S$ and $\ddot{U D S}$, and to determine the washback effects of these language tests on Turkish academics. In the study benefiting from a mixed-method design, a survey questionnaire was applied to 121 academics at Nevşehir University. The data were subject to both statistical and content analyses. The findings of the study revealed that $K P D S$ and $\ddot{U} D S$ prevented academics from doing academic/scientific studies. The academics reported that they could not concentrate on their academic work since they were required first to pass the language exams to be promoted. Considering the form and content of these language tests, $K P D S$ and $\ddot{U} D S$ seemed to eliminate academics instead of assessing their language proficiency. Moreover, KPDS and $\ddot{U D S}$ made academics more stressful and anxious about their future academic career and appeared to assess only test takers' grammar and reading skills while totally ignoring listening and productive skills. Considering all these findings, it could be asserted that KPDS and $\ddot{U} D S$ had negative washback effects on academics in Turkey. However, the study was limited to one university in Turkey; it could be conducted with more academics from different universities. Furthermore, an interview could be conducted with some academics that tried hard but could not pass language tests to gather more extended data and reach more generalizable results.

Similarly, Akpınar and Çakıldere (2013) investigated the washback effects of two high-stakes language tests namely KPDS and $\ddot{U} D S$ in Turkey. The researchers focused on the impacts of these tests on receptive and productive skills of Turkish academics. The participants of the study were 103 academics at Nevşehir University, Turkey. The participants were chosen among the academicians who failed those language exams despite studying hard for the exams. The data were 
collected using a survey questionnaire and were subject to descriptive and statistical analyses. The most striking finding of the study was that $K P D S$ and $\ddot{U} D S$ had positive washback effects on reading skill of the participants. As these language tests did not assess other skills such as writing, speaking and listening, test takers appeared to have studied to the test. As a result, it could be asserted that these language tests had negative washback effects on writing, listening and speaking skills of test takers. These findings were consistent with those of the study conducted by Yavuzer and Göver (2012). However, the number of the participants was significant but limited to one university. More academics could have been reached to make the study more enlightening. Moreover, since the data collection method was based on the responses provided to the questionnaire, the study could have benefited from interviews with the participants to enrich the findings.

Kilıçkaya (2016) conducted a study on the washback effect of the foreign language section of TEOG (Transition Examination from Primary to Secondary Education). The study aimed at determining the negative and positive washback effects of the language section of TEOG and its reflections on $8^{\text {th }}$-grade teachers' teaching practices. In the study benefiting from a qualitative research design, Kıliçkaya utilized content analysis and applied Kendall's Coefficient of Concordance Law. The participants of the study were 30 teachers teaching $8^{\text {th }}$ graders from 15 randomly chosen lower secondary schools in central Burdur, Turkey. The researcher used semistructured interviews and analyzed the exam papers prepared by the participants. The results of the study indicated that the content and the format of the language section of TEOG affected extensively language-teaching practices in these schools. Moreover, the main negative washback effect of TEOG was determined to be a barrier to cover the essential skills such as listening, speaking, and writing. Moreover, TEOG had a large influence on course book selection, the medium of instruction, classroom assessment, and learners' anxiety. Moreover, the students were placed into high schools based on the results of this exam, which created a negative washback effect on not only students but also teachers, parents, and administrators as a whole. 
The findings of the study indicated that some changes were needed about TEOG and its application to eliminate its nation-wide negative washback effects on mostly students. However, the study was limited to the teachers working in one city Burdur; more teachers from different cities could have been reached to gather more data. Furthermore, the study was conducted only with the teachers working in public schools; the teachers working at a private course for TEOG could have also been interviewed to enrich the findings.

In a similar study on washback in language testing in Turkey, Sayin and Aslan (2016) aimed to investigate the washback effects of the language section of LYS exam on ELT (English Language Teaching) undergraduate students. The researchers aimed to find out whether the exam was comprehensive enough to assess all the skills needed to learn a foreign language. Therefore, the researchers obtained the participants' views on the exam and asked them whether any changes in the structure and content of the exam were needed. The study benefited from a quantitative research design, and the data collection instrument included the questionnaire adapted from Karabulut's (2007) 'College Student Survey' with minor changes. The participants of the study were 74 Turkish freshmen ELT students, 59 of whom were female and the rest were male, studying at the two universities in Samsun, Turkey. After the analysis, the researchers found out that the skills such as listening and speaking were ignored not only in students' preparation process and in-class practice of LYS exam at school but also in the application of the written exam. On the other hand, "for the correct acquisition of language four skills must be included in the courses and assessment tests in the same proportion" (Sayin \& Aslan, 2016: 38). The students focused only on grammar and vocabulary, and LYS exam seemed to be not comprehensive enough since it did not assess competency in language. Most ELT students did not feel competent enough in their first year at the university. Thus, it could be stated that LYS had a negative washback effect on test takers. Students did not feel confident enough in speaking and listening although they passed the language exam and were admitted to the department. To sum up, while the study seemed 
to be largely impressive, only 74 students chosen from only two universities in one city might not be adequate to state that no ELT freshman students felt competent enough in their studies. Moreover, the lecturers' views could have also been obtained to triangulate the data obtained from the students' responses to the questionnaire.

Hatipoğlu (2016) investigated how pre-service English language teachers perceived and evaluated the effect of the ESUEE (English Section of University Entrance Exam) with respect to teaching and learning foreign languages in Turkey. The study benefited from qualitative and quantitative design, and a survey questionnaire and a semi-structured interview were used as the data collection instruments. The questionnaire had two sections; the first section requiring the demographic information of the participants and the second section relating to the effects of ESUEE. The interview was conducted with focus groups and mostly in Turkish. This study seemed to be significant and proficient with regard to the criticism of the ESUEE. The number of the participants, 50 pre-service English language teachers from METU (Middle East Technical University), Ankara, could be asserted to be satisfactory for this context. Besides, the results of the study indicated that almost all the participants believed that the exam affected and even directed how English was learned and taught in Turkey. In this context, the washback effect of EUEE was found out to be negative since ESUEE appeared to be the prevalent curriculum in English teaching and learning in Turkey. The results also revealed that most high school teachers did not teach English but helped the students master the format of ESUEE. Moreover, it was found out that the teachers trained the students to answer more questions correctly in the exam. However, the study was limited to METU; more participants from different universities in Ankara could have also participated in the study. In addition, the lecturers' views about ESUEE could have been obtained to see whether the lecturers' views were parallel to or conflicting with the students' views.

In his study on YDS, Külekçi (2016) carried out a brief and descriptive analysis of the exam. The structure of the exam was 
analyzed using Bachman and Palmer's (1996) 'language knowledge' dimension of the language use framework. In the study that benefited from a qualitative research design, Bachman and Palmer's (1996) test analysis checklist was slightly changed and applied by the researcher as a data collection tool. The structure and the sections of YDS exam were analyzed in terms of language knowledge and the researcher aimed to find out possible washback effects of the exam. One positive washback effect about the exam was that it stimulated test takers to study English more in order to get promotion in their profession or to get some amount of increment in their salaries with regard to their language proficiency level. On the other hand, one of the strongest negative washback effects of the exam was that test takers occasionally spent their time on flimsy language exams to improve their awareness and understanding multiple-choice technique. Apart from this, the exam primarily focused on grammatical and textual English disregarding practical usage of the language since it put aside the communicative and productive skills of a language use. After all, the study was limited by the lack of information since the researcher could not have analyzed all the questions in the exam since ÖSYM did not share all the questions. This study also lacked the analysis of test takers' views and suggestions about the exam. Therefore, other data collection instruments such as questionnaires and interviews could have been used in the study.

Similarly, Akın (2016) investigated YDS in terms of common characteristics of adult learning and language for specific purposes. The purpose of the study that benefited from qualitative research design was to find out whether there was a fair distribution of questions between the study fields in the test or not. In this descriptive study, document review was used on 2013 spring and 2015 fall YDS questions. The findings revealed that the test questions were not distributed among the academic fields of candidates properly. Furthermore, the test assessed only test takers' reading, vocabulary and grammar skills. Listening, speaking, and writing skills of test takers were not assessed, which uncovered a negative washback effect of YDS on test takers. These results were consistent with those of the 
study conducted by Külekçi (2016). However, the findings of the study did not appear to be reliable since the researcher could analyze only 10 percent of all the questions in 2013 spring YDS and 2015 fall $Y D S$. This is due to the fact that ÖSYM did not share the rest of the questions with the public. Furthermore, the study seemed to be only benefiting from the qualitative research method; an interview or a survey questionnaire could be applied with a number of test takers in order to enrich the data obtained from document review of the test. In addition, it could be investigated whether there were any similarities between test takers' academic interests and the topics covered in YDS questions.

In another study, Yeşilyurt (2016) investigated academicians' perceptions and experiences about the national high-stakes FLTs (Foreign Language Tests) such as YDS and its counterparts applied at different times in Turkish contexts. The purpose of the study was to deepen FLT perception in Turkey using metaphor elicitation. Therefore, metaphor elicitation was used in the study benefiting from qualitative research design. A questionnaire was applied to 110 academicians from Atatürk University, Turkey. In this questionnaire, participants were asked to write a metaphor for FLTs in Turkey and short justifications for the metaphor they produced. After the data analysis, 68 metaphors out of 110 were identified to be valid for the study and were subject to content analysis. The findings of the study revealed it took much time for test takers to pass FLTs in Turkey, and the test takers experienced large difficulties studying for FLTs. In addition, most participants appeared to have conceptualized FLTs as an obstacle for their future scientific studies. Moreover, most of the participants of the study stated negative opinions about the structure, scope, quality, and utility of these language tests. Thus, it could be asserted that FLTs applied in Turkish contexts seemed to have negative washback effects on test takers influencing their both personal and professional life. However, the study was conducted with a limited number of participants from only one state university in Turkey; more academicians from different universities could have participated in the study. Moreover, the data could also be evaluated 
in relation to different variables such as gender, major and proficiency level of the participants. Furthermore, quantitative research design could also be used in the study to provide triangulation of the quantitative and qualitative data and thereby to yield more enlightening and generalizable results.

3. The studies conducted on washback effects of exams in state and private schools in Turkey

Apart from studies conducted on washback effects of high-stakes exams in Turkey, there were other studies about washback effects of exams in state and private schools in Turkey. These schools have a significant number of students; therefore, studying washback effects of the exams applied in these schools could contribute much to English language teaching. In that sense, the current paper aims to summarize some of the studies conducted in these state and private institutions in Turkey to determine washback effects of the relevant exams as indicated by the studies within this frame.

To start with, Şenel and Tütüniş (2011) studied negative washback effects of testing on EFL (English as a Foreign Language) students' writing at the English Preparatory School of Aydin University in İstanbul, Turkey. The study was based on experimental research design benefiting from qualitative and quantitative analyses. The participants of the study were 42 students studying at the university, and they were grouped into experimental and control groups. A questionnaire was given to both groups, and they were both observed by the researcher over the period of two weeks. The findings indicated that EFL learners' uneasiness about writing was triggered by some basic factors such as lack of vocabulary, lack of grammar and syntax knowledge, fear of failure, fear of negative evaluation, and time limit. Furthermore, language anxiety appeared to result from fear of making mistakes and using wrong expressions. Thus, as a result, it could be stated that this kind of writing exams applied in Turkish universities would probably have negative washback effects on university students. Moreover, language learners might feel comfortable and unstressed in the exam as long as they were not informed that it was 
an assessment. For further research, the relationship between testing anxiety and gender, age and learner disabilities could be investigated as well.

Sarıçoban (2011) studied washback effects in language testing in Turkey. The focus of the study was to investigate the current situation in testing, and the researcher aimed to find out whether traditional methods were still used. In order to see the ongoing case, Sarıçoban used the document analysis technique. The study, benefiting from the qualitative research design, was conducted at a state high school in Ankara. Samples of two exams written by five teachers were collected by 16 teacher trainees. It was found that teaching and testing did not correspond with each other, and teachers did not include the topics that were covered in class in the exams they prepared. Nevertheless, as Köksal (2004) states, "the tasks that we expect our students to perform in classroom activities must be in concert with the tasks they are asked to in tests" (p. 6). Moreover, in some cases, the teachers asked about the topics that were not covered in the class. Thus, this could be a negative washback effect for students. To sum up, this study aimed to underscore some issues about testing and negative washback; however, considering the number of the exams analyzed, it might not be enough to create a definite statement about possible negative washback effects of the exams conducted in this state high school.

Similarly, Paker (2012) investigated the content of the achievement tests given in various preparatory programs in Schools of Foreign Languages of 13 universities in Turkey in terms of the four language skills and language use. The aim of the study was to analyze types of test items and tasks used in these exams and their possible washback effects on not only learning but also teaching processes. Based on the qualitative research design, the study benefited from document analysis on these achievement tests. The study revealed that all skills and subskills were somehow tested in almost all the schools. Thus, it could be asserted that all these language exams might have had positive washback effects on students since these exams prepared exam takers for their future academic life. Although the study focused 
on washback in language testing and analyzed the exams, it was not possible to analyze the speaking tests applied in these schools since all these schools had different methods of assessing this productive skill.

In their study, Cinkara and Tosun (2017) investigated the face validity of a language test applied in School of Foreign Languages in Gaziantep, Turkey. The purpose of the study was to find out whether test designers' intentions coincide with test takers' expectations of a test. The researchers aimed to find out whether there was a similarity or a difference between test takers' and test designers' perceptions of a test applied in the school. The study benefiting from both qualitative and quantitative research design included 49 participants, all of whom were either working or studying in School of Foreign Languages at Gaziantep University. 38 of the participants were the engineering students at an intermediate level in module B1, while 7 of them were course instructors and the remaining 4 were test designers. Response sheets and interviews were used as data collection tools for the study. The results of the study indicated that students were of the idea that the test did not meet their expectations of a test; therefore, the face validity of the test could be claimed to be low. Moreover, test takers asserted that the test was not strong enough in terms of assessing the necessary skills in language learning, which indicated the negative washback of this test on test takers. On the other hand, the number of participants being interviewed appeared to be unsatisfactory; more test takers could be interviewed to enrich the findings. The participants were also limited to engineering students; more students from different departments could have participated in the study. Furthermore, the study did not examine the relationship between test takers' understanding of face validity of the test and test takers' proficiency level in English. Analyzing the relationship between test takers' attitudes about face validity of the test and their proficiency level in English could yield more enlightening results.

\section{Conclusion}

The main goal of the current study was to analyze the studies conducted on the washback effect of "nation-wide" and "teacher 
made" language exams in Turkey between 2010 and 2017. Since washback is relatively a new issue in language learning and teaching, there are few studies on this current topic; however, this number is increasing day by day as Özmen (2011b) suggests "the number of studies on washback effect in language testing literature has been growing rapidly due to its critical impact on learning, learners and teachers and even the society or the complete educational system of a country" (p. 224). Based on the findings of the studies conducted on high-stakes language exams in Turkey, it could be inferred that these national exams just focus on recognition skills as they deal with multiple-choice questions and they ignore the productive skills (writing and speaking) and the receptive skill of listening. Moreover, these exams appear to be barriers to test takers' future personal/professional lives and create much anxiety for test takers. Similarly, the exams in state and private schools in Turkey seem to assess only reading, grammar and vocabulary ignoring other receptive and productive skills, namely listening and speaking. These tests lead to narrowing of the curriculum in schools and make teachers teach to the test. Students appear to master the format of these tests instead of acquiring the necessary skills for language learning.

For further studies, it could be examined whether there is a significant difference between the washback effects of the high-stakes language exams in Turkey and the test takers' gender, age, major and proficiency level. Furthermore, test takers' views and suggestions about these national exams could be investigated. Since these nationwide exams are conducted in most of the cities in Turkey, a larger number of participants from different regions of Turkey could be included in the future studies. The findings of those studies could be discussed in terms of the washback effects of these exams according to test takers' cities or regions. Moreover, the washback effects of other high-stakes language exams in Turkey, namely IELTS (International English Language System) and TOEFL (Test of English as a Foreign Language) could be investigated in further studies. Whether positive or negative, it is not a question of matter that all exams directly impact students, teachers, and administrators, and 
indirectly schools and communities. It could be concluded that highstakes exams have larger effects on test takers, from preparation expenses to admission to university programs; therefore, it is not surprising that most studies on washback in language testing in Turkey are based on these national examinations and their washback effect on examinees.

Acknowledgement

This article is the extended version of the paper presented at the 3rd International Language, Culture \& Literature Symposium at Akdeniz University, Turkey, on June $15,2017$.

References

Akın, G. 2016. Evaluation of national foreign language test in Turkey. Asian Journal of Educational Research, 4(3), 11-21. Retrieved from http://www.multidisciplinaryjournals.com/wp-content/uploads/2016/04/FULLPAPER-EVALUATION-OF-NATIONAL-FOREIGN-LANGUAGE-TEST-INTURKEY.pdf

Akpınar, K. D., Çakıldere, B. 2013. Washback effects of high-stakes language tests of Turkey (KPDS and ÜDS) on productive and receptive skills of academic personnel. Journal of Language and Linguistic Studies, 9(2), 81-94. Retrieved from http://dergipark.ulakbim.gov.tr/jlls/article/download/5000084297/5000078394

Alderson, J. C., Wall, D. 1993. Does washback exist? Applied Linguistics, 14(2), 115129.

Bachman, L. F., Palmer, A. S. 1996. Language Testing in Practice. Oxford: Oxford University Press.

Brown, H. D., Abeywickrama, P. 2010. Language Assessment: Principles and Classroom Practice (2nd ed.). New York: Pearson Education.

Cinkara, E., Tosun, Ö. Ö. 2017. Face validity study of a small-scale test in a tertiarylevel intensive EFL program. B.U. Journal of Faculty of Education, 6(2), 395410.

Glaser, B. G., Strauss, A. L. 1967. The Discovery of Grounded Theory. New York: Aldine.

Hatipoğlu, Ç. 2016. The impact of the university entrance exam on EFL education in Turkey: Pre-service English language teachers' perspective. Procedia-Social and Behavioral Sciences, 232, 136-144.

Hughes, A. 2003. Testing for Language Teachers (2nd ed.). Cambridge: Cambridge University Press. 
Karabulut, A. 2007. Micro Level Impacts of Foreign Language Test (University Entrance Examination) in Turkey: A Washback Study. (MA thesis). ProQuest Information and Learning Company. UMI: 1448691. Retrieved from http://lib.dr.iastate.edu/cgi/viewcontent.cgi?article=15883\&context=rtd

Kılıçkaya, F. 2016. Washback effects of a high-stakes exam on lower secondary school English teachers' practices in the classroom. Lublin Studies in Modern Languages and Literature, 40(1), 116-134. Retrieved from http://journals.umcs.pl/1smll/article/view/2167/2877

Köksal, D. 2004. Assessing teachers' testing skills in ELT and enhancing their professional development in testing and assessment through distance learning on the NET. Turkish Online Journal of Distance Education, 5(1). Retrieved from http://tojde.anadolu.edu.tr/yonetim/icerik/makaleler/121-published.pdf

Külekçi, E. 2016. A concise analysis of the Foreign Language Examination (YDS) in Turkey and its possible washback effects. International Online Journal of Education and Teaching, 3(4), 303-315. Retrieved from http://iojet.org/index.php/IOJET/article/view/141/143

Özmen, K. S. 2011a. Analyzing washback effect of SEPPPO on prospective English teachers. The Journal of Language and Linguistic Studies, 7(2), 24-52. Retrieved from http://www.jlls.org/index.php/jlls/article/view/112/

Özmen, K. S. 2011b. Washback effects of the inter-university foreign language examination on foreign language competences of candidate academics. NovitasROYAL (Research on Youth and Language), 5(2), 215-228. Retrieved from http://www.novitasroyal.org/Vol_5_2/OzmenKS.pdf

Paker, T. 2012. The backwash effect of the test items in the achievement exams in preparatory classes. Procedia-Social and Behavioral Sciences, 70, 1463-1471.

Sarıçoban, A. 2011. A study on the English language teachers' preparation of tests. $H$. U. Journal of Education, 41, 398-410. Retrieved from http://www.efdergi.hacettepe.edu.tr/makale_goster.php?id=709

Sayın, B. A., Aslan, M. M. 2016. The negative effects of undergraduate placement examination of English (LYS-5) on ELT students in Turkey. Participatory Educational Research, 3(1), 30-39.

Şenel, E., Tütüniş, B. 2011. The washback effect of testing on students' learning in EFL writing classes. Dil Dergisi, 153, 43-52. Retrieved from http://dergiler.ankara.edu.tr/dergiler/27/1831/19272.pdf

Yavuzer, H., Göver, İ. H. 2012. Akademik personelin yabancı dil durumu ve yabancı dil sınavlarına bakışı: Nevşehir örneği [The academics' language proficiency and their views on foreign language exams: Nevşehir Example]. NEÜ Sosyal Bilimler Enstitüsü Dergisi, 1(2), 136-158. Retrieved from http://dergipark.ulakbim.gov.tr/nevsosbilen/article/download/1043000099/104300 $\underline{0057}$ 
Yeşilyurt, S. 2016. An attempt for the exploration of academicians' experiences of the standard foreign language tests held in Turkey through metaphors. International Journal of Higher Education, 5(2), 263-274.

Yıldırım, Ö. 2010. Washback effects of a high-stakes university entrance exam: Effects of the English section of the university entrance exam on future language teachers in Turkey. The Asian EFL Journal Quarterly, 12(2), 92-116. Retrieved from http://www.asian-efl-journal.com/PDF/June-2010.pdf 